\title{
Registration of 'Quest' Spring Malting Barley with Improved Resistance to Fusarium Head Blight
}

\author{
K. P. Smith,* A. Budde, R. Dill-Macky, D. C. Rasmusson, E. Schiefelbein, B. Steffenson, \\ J. J. Wiersma, J. V. Wiersma, and B. Zhang
}

\begin{abstract}
'Quest' (Reg No. CV-348, PI 663183) is a spring, six-rowed, malting barley (Hordeum vulgare L.) released by the Minnesota Agricultural Experiment Station in January 2010 on the basis of its improved resistance to Fusarium head blight [FHB; caused by Fusarium graminearum Schwabe; teleomorph Gibberella zeae (Schwein) Petch]. Quest was developed over three breeding cycles of selection for yield, malting quality, and FHB resistance. Disease resistance traces to the Midwest cultivar MNBrite and the two-rowed accession from China Zhedar1. Quest has about half the level of disease and about $40 \%$ less of the associated mycotoxin, deoxynivalenol, compared to the historically important cultivar in the region

'Robust'. Quest is similar in yield to the current dominant varieties in the region and was approved as a malting variety by the American Malting Barley Association.
\end{abstract}

'O uest' (Reg No. CV-348, PI 663183) is a spring, sixrowed, malting barley (Hordeum vulgare L.) cultivar released by the Minnesota Agricultural Experiment Station in 2010 that provides growers in the midwestern United States with an additional tool to manage the risks associated with Fusarium head blight [FHB; caused by Fusarium graminearum Schwabe; teleomorph Gibberella zeae (Schwein) Petch]. Quest was tested in the Mississippi Valley Barley Nursery (MVBN) under the experimental line number M122 from 2005 to 2006 and was entered into American Malting

K.P. Smith, D.C. Rasmusson, E. Schiefelbein, and J.J. Wiersma, Dep. of Agronomy and Plant Genetics, Univ. of Minnesota, 409 Borlaug Hall, 1991 Upper Buford Cir., St. Paul, MN 55108; A. Budde (retired), USDA-ARS, Cereal Crops Research Unit, 502 Walnut St., Madison, WI 53705; R. Dill-Macky and B. Steffenson, Dep. of Plant Pathology, Univ. of Minnesota, 495 Borlaug Hall, 1991 Upper Buford Cir., St. Paul, MN 55108; J.V. Wiersma, Northwest Research and Outreach Center, Crookston, MN; B. Zhang, Zheijiang Univ., Hangzhou, China. *Corresponding author (smith376@umn.edu).

Abbreviations: AMBA, American Malting Barley Association; DON, deoxynivalenol; FHB, Fusarium head blight; HSD, honestly significant difference; MVBN, Mississippi Valley Barley Nursery; NABSEN, North American Scab Evaluation Nursery; RCBD, randomized complete block design.

Published in the Journal of Plant Registrations. doi: 10.3198/jpr2012.03.0200crc

Received 22 Mar. 2012. Registration by CSSA

(C) Crop Science Society of America

5585 Guilford Rd., Madison, WI 53711 USA

All rights reserved. No part of this periodical may be reproduced or transmitted in any form or by any means, electronic or mechanical, including photocopying, recording, or any information storage and retrieval system, without permission in writing from the publisher. Permission for printing and for reprinting the material contained herein has been obtained by the publisher.
Barley Association (AMBA) pilot malting evaluations in 2005 and plant-scale brewing evaluations in 2008. Quest was released based on its enhanced resistance to FHB and lower levels of the associated mycotoxin deoxynivalenol (DON), good agronomic performance in the U.S. Midwest, and acceptable malting quality.

Fusarium head blight is a serious disease problem on both wheat (Triticum aestivum L.) and barley in the United States. In the case of barley, the Midwest region, including Minnesota, North Dakota, and South Dakota, has experienced serious disease outbreaks since the early 1990s (Nganje et al., 2004). Diseased grain accumulates the toxin DON and becomes unusable for malting and brewing and in extreme cases is rejected for use as feed. Fungicides can provide partial protection from the disease and reduce the level of DON. The increased risk due to FHB associated with producing barley has contributed to the dramatic decline in acreage in this region. Cultivars like Quest, which have enhanced resistance, in combination with other disease management practices should lessen risks and increase opportunities to produce barley in regions where the disease is prevalent (McMullen et al., 2008)

\section{Methods \\ Parentage and Early-Generation Population Development}

Quest is a selection from the cross FEG18-20/M110. FEG1820 was a line selected for partial resistance to FHB based on several years of disease screening from the cross 'MNBrite' (PI 603050)/SI4-29 (Rasmusson et al., 1999). MNBrite is a cultivar that has improved resistance to kernel discoloration and FHB; however, it did not meet industry standards as a malting variety (Canci et al., 2003). SI4-29 was also selected 
for partial resistance to FHB from the cross Zhedar1/'Stander' (PI 56743)//'Foster' (PI 592758), which was given to us by Dr. R. Horsley as $\mathrm{F}_{2}$ seed in 1994 (Rasmusson et al., 1993; Horsley et al., 1997). Zhedar1 is a two-rowed accession from China that was identified as having resistance to FHB (Urrea et al., 2005). M110 is a cultivar candidate from the University of Minnesota breeding program that was evaluated in the Mississippi Valley Regional Nursery (MVBN) in 2001-2002 and is an advanced cycle breeding line that has the cultivars Nordic (CIho 15216), Manker (CIho 15549), Robust (PI 476976), Excel (PI 542047), and Stander in its pedigree (Rasmusson and Banttari, 1975, Rasmusson and Wilcoxson, 1983, Rasmusson et al., 1991, 1993).

The cross leading to Quest was made in the fall of 2000. The $F_{1}$ was grown in the greenhouse in the winter of 2001, and the $\mathrm{F}_{2}$ seeds were planted in single-row plots that were $2 \mathrm{~m}$ in length with $30-\mathrm{cm}$ row spacing in April 2001. A single spike was harvested from each $\mathrm{F}_{2}$ plant, and a single $\mathrm{F}_{2: 3}$ seed was planted from each spike in pots in the greenhouse in August 2001. A single seed was harvested from each $\mathrm{F}_{2: 3}$ plant, and approximately $200 \mathrm{~F}_{3: 4}$ seeds were planted in lightly seeded rows in an off-season nursery near Yuma, AZ in November of 2001.

\section{Line Selection and Evaluation}

A total of $76 \mathrm{~F}_{3: 4}$ plants tracing to FEG18-20/M110 were individually harvested in the spring of 2002, and the seed was sown into $1.3-\mathrm{m}$ single-row plots arranged in a randomized complete block design (RCBD) with two replications in three FHB nurseries located in Crookston, MN and Morris, MN in April 2002 and in Hangzhou, China in 2003. These nurseries were inoculated with grain spawn and mist irrigated to promote disease as described by Mesfin et al. (2003). In these early trials, the breeding line that would become Quest, FEG65-02, was selected based on low disease severity for FHB and low levels of DON from harvested grain samples as well as on visual assessment of maturity, plant height, and lodging. A bulk of the $\mathrm{F}_{4: 6}$ seed harvested from one of the FHB plots was sown in 30 pots in the greenhouse. The $\mathrm{F}_{4: 7}$ seed harvested from these plants was used for replicated field trials beginning in 2003.

Preliminary yield trials were conducted in 2003 at St. Paul and Crookston, MN in an RCBD with three replicates in two-row plots $3 \mathrm{~m}$ in length spaced $30 \mathrm{~cm}$ apart and seeded at a rate of $108 \mathrm{~kg} \mathrm{ha}^{-1}$. All subsequent yield trials (2004-2010) were conducted in St. Paul, Crookston, Morris, Stephen, and Roseau, MN in randomized complete block experiments with three replicates in 1.4- by $3-\mathrm{m}$ plots with $18-\mathrm{cm}$ row spacing and the same seeding rate. Quest was evaluated as part of the Minnesota state yield trials from 2005-2010. Yields were based on grain harvested from plots end-trimmed to $2.4 \mathrm{~m}$ in length. Percentage plump kernels were determined by calculating the percentage, by weight, of kernels that did not pass through a 0.24by $1.9-\mathrm{cm}$ sieve. Malt quality was evaluated on a $400-\mathrm{g}$ subsample of a composite sample from all the replicates of a trial by the USDA-ARS Cereal Crops Research Unit in Madison, WI using their standard protocols (http://www .ars.usda.gov/SP2UserFiles/Place/36551000/barleyreports/
CY\%20METHODS.pdf; accessed 4 Dec. 2012). FEG6502 was assigned the cultivar candidate designation M122 and evaluated in the MVBN from 2005 to 2006. M122 was evaluated at the five locations of the Red River Valley On-Farm Trials from 2006 to 2010 for a total of 17 trials. Entries were solid-seeded in 1.5- by $6.1-\mathrm{m}$ plots in an RCBD with two replicates using a seeding rate (corrected for seed count per kilogram and percentage germination) between 135 and $167 \mathrm{~kg} \mathrm{ha}^{-1}$. M122 was evaluated in AMBA pilot malt tests with grain from the 2005 and 2006 crop years. It was evaluated in AMBA plant-scale brewing tests with grain from the 2008 and 2009 crop years. After favorable evaluation, M122 was released as the cultivar Quest and added to the list of AMBA-recommended cultivars in 2010 (www.ambainc.org; accessed 16 July 2012).

\section{Evaluation in Replicated Trials}

Twenty-four trials from the Minnesota State Cultivar Trials that included the comparison cultivars Robust, Conlon (PI 597789), Lacey (PI 613603), Stellar-ND (PI 639694), Tradition (PI 612442; a cultivar developed by Busch Agriculture Resources Inc.), and 'Rasmusson' (PI 658495) were used in the analyses of agronomic traits (Rasmusson et al., 2001; Horsley et al., 2006; Smith et al., 2010). Tradition and Lacey had the largest acreage in the U.S. Midwest in 2010 and are currently the malting quality standards for the industry (www.ambainc.org) and are therefore useful for comparison. Robust was the leading cultivar in the region from 1985 to 2005 and is still used as a malting quality check by the industry. Conlon is a two-rowed cultivar that is grown in the region for malting, and two-rowed cultivars have typically been observed to have less FHB than six-rowed cultivars, making it another useful comparison. Seventeen trials from the Red River Valley On-Farm trials that included the cultivars Robust, Legacy, Lacey, Tradition, Stellar-ND, and Rasmusson were used in the analyses of agronomic traits. Six trials from the MVBN that included the above cultivars were used for malting-quality analyses. Composite samples from each trial were malted, and the analysis was conducted across trials.

Disease reactions for foliar diseases were assessed in a combination of field and greenhouse assays conducted from 2002 to 2008. Septoria speckled leaf blotch (caused by Septoria passerinii Sacc.) and the net form of net blotch (caused by Pyrenophora teres f. sp. teres Drechs) were evaluated in the greenhouse in 2006, 2007, and 2008 with the methods of Toubia-Rahme and Steffenson (2004) and St. Pierre et al. (2010), respectively. Stem rust (caused by Puccinia graminis f. sp. tritici Pers.: Pers) and spot blotch ([caused by Cochliobolus sativus (Ito and Kuribayashi) Drechs. ex Dastur] were evaluated in field nurseries at St. Paul, MN in 2002 and 2003 according to the methods of Steffenson et al. (1993) and Fetch et al. (2008), respectively. For each of these diseases, cultivars were given a disease reaction score from 1 (resistant) to 9 (susceptible) based on comparative data for at least two experiments. During the selection of Quest, FHB was evaluated in the field at St. Paul, Morris, and Crookston, MN and in Hangzhou, China from 2003 to 2010 using the grain spawn and conidial spray methods 
described by Steffenson (2003). Disease was assessed by estimating the percentage of infected kernels on individual spikes according to the following scale $(0,1,3,5,10,15,25$, $35,50,76,100 \%)$. An arbitrary sample of either 10 or 20 spikes, depending on the severity of disease in the nursery, was visually assessed and averaged for each plot. Plots were harvested by hand or using a single-row plot binder; the grain was threshed and cleaned; and approximately $20 \mathrm{~g}$ of grain was ground in preparation for DON analysis, which was conducted with gas chromatography and mass spectrometry (Mirocha et al., 1998; Fuentes et al., 2005). Quest was evaluated in the North American Scab Evaluation Nursery (NABSEN) in 2004-2007 by collaborators using the methods described above. The NABSEN is grown annually at multiple locations in the Midwest and Canada in an RCBD with three replications. Quest was added to the NABSEN as moderately resistant check in 2010.

Statistical analyses for these trials were conducted using SAS for Windows version 9.2 (SAS Institute Inc.). Each location-year was treated as an environment, and all analyses were conducted on the means for each environment. Bartlett's test was used to test for homogeneity of variances among environments before combining environments in the analysis. The FHB severity and DON data were transformed by square root to reduce heterogeneity of variances. For FHB and DON analyses, mean comparisons were done on the transformed values; however, the untransformed values are presented. Mixed-model analysis was performed with the cultivar as a fixed effect and environment as a random effect. Mean separation tests were based on Tukey's honestly significant difference (HSD; $\alpha=0.05)$.

\section{Seed Purification and Increase}

In 2005, approximately 50 single spikes were harvested from $\mathrm{F}_{4: 9}$ plants growing in a winter nursery in New Zealand and planted as headrows in St. Paul. All rows appeared uniform and were harvested and bulked to form the $\mathrm{F}_{4: 10}$ breeder seed. a white aleurone, veins with few barbs, and a crease that is V-shaped and narrow to closed at the base. The hull is adhering and wrinkled.

\section{Grain Yield and Quality Performance}

In state yield trials conducted from 2005 to 2010 at a total of 24 trials, Quest was similar in yield to the two most popular cultivars Lacey and Tradition (Table 1). In on-farm trials conducted in the Red River Valley, Quest was again very similar in yield to Lacey and Tradition (Table 2). Quest has a very favorable malting quality profile, which contributed to its addition to the AMBA list of recommended malting varieties in 2011. Quest is similar to the other malting varieties with respect to barley protein and malt extract (Table 3). Its soluble protein and ratio of soluble to total protein $(\mathrm{S} / \mathrm{T})$ are similar to those of Tradition and Lacey, but less than Legacy. Diastatic power is slightly lower than Tradition and

\section{Table 1. Agronomic performance of Quest and check cultivars from 2005 to 2010 in Minnesota State Yield Trials (24 location-years). ${ }^{\dagger}$}

\begin{tabular}{|c|c|c|c|c|}
\hline Entry & $\begin{array}{l}\text { Grain } \\
\text { yield }\end{array}$ & $\begin{array}{c}\text { Plant } \\
\text { height }^{\ddagger}\end{array}$ & $\begin{array}{l}\text { Heading } \\
\text { date }\end{array}$ & Lodging \\
\hline & $\mathrm{kg} \mathrm{ha}^{-1}$ & $\mathrm{~cm}$ & $\begin{array}{l}\text { d from } \\
\text { planting }\end{array}$ & $1-9^{\S}$ \\
\hline Robust & 4890 & 84.9 & 55.9 & 4.9 \\
\hline Conlon & 5060 & 77.8 & 53.4 & 5.2 \\
\hline Lacey & 5356 & 78.8 & 56.2 & 3.8 \\
\hline Stellar-ND & 5057 & 79.6 & 55.5 & 3.2 \\
\hline Tradition & 5411 & 80.2 & 57.0 & 3.8 \\
\hline Rasmusson & 5517 & 76.1 & 55.4 & 4.2 \\
\hline Quest & 5415 & 81.6 & 56.2 & 4.8 \\
\hline HSD $(0.05)^{\Uparrow}$ & 491 & 3.2 & 0.8 & ns \\
\hline CV\% & 8.4 & 3.9 & 1.7 & - \\
\hline \multicolumn{5}{|c|}{$\begin{array}{l}\text { ¡Locations of state trials were St. Paul, Morris, Crookston, Stephen, and } \\
\text { Roseau, MN. }\end{array}$} \\
\hline \multicolumn{5}{|c|}{$\begin{array}{l}\text { fHeight was recorded at } 17 \text { trials, heading date at } 19 \text { trials, and lodging at } 6 \text { trials } \\
\$ 1=\text { most resistant; } 9=\text { most susceptible. }\end{array}$} \\
\hline \multicolumn{5}{|c|}{ "Tukey's honestly significant difference $(\alpha=0.05)$. } \\
\hline
\end{tabular}

\section{Characteristics Agronomic and Botanical Description}

Quest heads at the same time as other six-rowed cultivars that are grown in the region and is intermediate in height between Lacey and Robust (Table 1). Lodging resistance is slightly less than Tradition and Lacey, however not significantly (Tables 1 and 2). The volume weight of Quest is also slightly lower than Tradition and Lacey. Grain protein concentration and kernel plumpness for Quest are similar to the other six-rowed cultivars. Quest is not as plump as Stellar-ND.

The spike of Quest has semismooth awns, long rachilla hairs, and glume hairs that are completely covered. The kernel has

Table 2. Agronomic performance of Quest and check cultivars from 20062010 Red River Valley On-Farm Trials (17 location-years). ${ }^{\dagger}$

\begin{tabular}{|c|c|c|c|c|c|c|}
\hline Cultivar & $\begin{array}{l}\text { Grain } \\
\text { yield }\end{array}$ & $\begin{array}{l}\text { Volume } \\
\text { weight }\end{array}$ & $\begin{array}{l}\text { Grain } \\
\text { protein }\end{array}$ & Plump & $\begin{array}{l}\text { Plant } \\
\text { height }\end{array}$ & Lodging \\
\hline & $\mathrm{kg} \mathrm{ha}^{-1}$ & $\mathrm{~kg} \mathrm{~m}^{3}$ & \multicolumn{2}{|c|}{$\%$} & $\mathrm{~cm}$ & $1-9^{\ddagger}$ \\
\hline Robust & 5944 & 580.2 & 13.2 & 79.0 & 87.3 & 2.6 \\
\hline Legacy & 6184 & 553.6 & 12.7 & 75.4 & 83.4 & 2.8 \\
\hline Lacey & 6376 & 592.5 & 13.1 & 81.7 & 82.4 & 2.5 \\
\hline Stellar-ND & 6417 & 573.4 & 12.6 & 84.5 & 85.7 & 2.2 \\
\hline Tradition & 6229 & 580.1 & 12.9 & 82.6 & 83.9 & 2.2 \\
\hline Rasmusson & 6635 & 581.7 & 12.7 & 77.9 & 81.0 & 2.5 \\
\hline Quest & 6344 & 563.2 & 12.8 & 77.8 & 84.2 & 3.0 \\
\hline HSD $(0.05)^{\S}$ & 426 & 14.0 & 0.5 & 5.1 & 3.3 & ns \\
\hline CV\% & 11.4 & 4.0 & 5.4 & 11.0 & 6.2 & - \\
\hline \multicolumn{7}{|c|}{$\begin{array}{l}\text { ¡Locations of Red River Valley On-farm Trials were Fergus Falls, Oklee, Perley, Strathcona, and } \\
\text { Humboldt, MN. }\end{array}$} \\
\hline \multicolumn{7}{|c|}{$\neq_{1}=$ most resistant; 9 = most susceptible. } \\
\hline \multicolumn{7}{|c|}{ §Tukey's honestly significant difference ( $\alpha=0.05)$. } \\
\hline
\end{tabular}


Table 3. Malting quality profile of Quest compared to other cultivars in the Mississippi Valley Barely Nursery in 20052006 (mean of six trials). ${ }^{\dagger}$

\begin{tabular}{|c|c|c|c|c|c|c|c|c|c|c|c|}
\hline Cultivar & $\begin{array}{l}\text { Kernel } \\
\text { weight }\end{array}$ & $\begin{array}{l}\text { Plump } \\
\text { kernels }\end{array}$ & $\begin{array}{l}\text { Barley } \\
\text { protein }\end{array}$ & $\begin{array}{c}\text { Malt } \\
\text { extract }\end{array}$ & $\begin{array}{l}\text { Soluble } \\
\text { protein }\end{array}$ & $\begin{array}{c}\text { Soluble/ } \\
\text { total } \\
\text { protein }\end{array}$ & $\begin{array}{c}\text { Diastatic } \\
\text { power }\end{array}$ & $\alpha$-Amylase & $\beta$-Glucan & $\begin{array}{c}\text { Free } \\
\text { amino } \\
\text { nitrogen }\end{array}$ & Turbidity \\
\hline & $\mathrm{mg}$ & 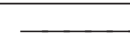 & 2 & $\%$ & 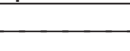 & + & ${ }^{\circ} \mathrm{ASBC} \mathrm{C}^{\ddagger}$ & D.U. $\S$ & $\mathrm{mg} \mathrm{L}^{-1}$ & $\mathrm{mg} \mathrm{kg}^{-1}$ & NTUף \\
\hline Robust & 35.3 & 86.1 & 13.2 & 79.2 & 5.7 & 44.7 & 162.7 & 53.8 & 222.0 & 254.2 & 5.2 \\
\hline Legacy & 34.0 & 81.8 & 12.8 & 79.5 & 6.1 & 48.9 & 162.5 & 74.0 & 213.8 & 267.2 & 6.4 \\
\hline Lacey & 36.3 & 87.8 & 13.2 & 79.6 & 5.7 & 44.7 & 159.3 & 64.6 & 106.7 & 240.8 & 10.1 \\
\hline Stellar-ND & 36.0 & 91.2 & 12.9 & 79.5 & 5.6 & 44.7 & 165.5 & 65.6 & 96.7 & 239.8 & 12.4 \\
\hline Tradition & 34.3 & 86.8 & 12.9 & 79.3 & 5.3 & 42.6 & 178.2 & 66.1 & 135.8 & 211.2 & 13.2 \\
\hline Celebration & 32.5 & 84.1 & 13.3 & 79.6 & 5.8 & 45.6 & 179.7 & 71.5 & 112.7 & 244.2 & 5.7 \\
\hline Quest & 34.7 & 83.2 & 12.9 & 79.3 & 5.7 & 45.5 & 157.5 & 67.8 & 196.0 & 239.0 & 5.3 \\
\hline $\operatorname{HSD}(p=0.05)^{\#}$ & 1.6 & 5.1 & ns & ns & 0.4 & 3.3 & 24.8 & 8.4 & 76.4 & 48.0 & ns \\
\hline CV\% & 0.02 & 0.03 & - & - & 0.04 & 0.04 & 0.08 & 0.07 & 0.27 & 0.11 & - \\
\hline
\end{tabular}

TTrials conducted at Crookston, MN 2005; Morris, MN 2005 and 2006; Fargo, ND 2006; Osnabrock, ND 2006; Sidney, MT 2006.

†Strength of starch reducing enzyme in malt as determined by Methods of Analysis of the ASBC, 8th ed, 1992.

§Enzyme activity in dextrinizing units.

"Nephelometric turbidity units.

\#Tukey's honestly significant difference $(\alpha=0.05)$.

Table 4. Disease reaction of Quest compared to other barley cultivars to stem rust, spot blotch, net form of net blotch, Septoria speckled leaf blotch (SSLB), and Fusarium head blight (FHB).

\begin{tabular}{lccccc}
\hline Cultivar & FHB & $\begin{array}{c}\text { Net } \\
\text { blotch }\end{array}$ & SSLB & $\begin{array}{c}\text { Spot } \\
\text { blotch }\end{array}$ & $\begin{array}{c}\text { Stem } \\
\text { rust }^{+}\end{array}$ \\
\cline { 2 - 6 } Lacey & 8 & 8 & $1-99^{\ddagger}$ & & \\
Legacy & 7 & 5 & 9 & 2 & 1 \\
MNBrite & 6 & 6 & 9 & 1 & 1 \\
Quest & 5 & 8 & 9 & 2 & 1 \\
Rasmusson & 8 & 9 & 9 & 2 & 1 \\
Robust & 8 & 8 & 9 & 2 & 1 \\
Tradition & 8 & 7 & 9 & 2 & 1 \\
\hline
\end{tabular}

${ }^{\dagger}$ Reaction to the dominant strain of the stem rust pathogen.

$\ddagger 1=$ most resistant $; 9$ = most susceptible.

Celebration but not significantly, based on the conservative HSD (0.05) test. All of the newer varieties, including Quest, are higher in $\alpha$ amylase compared to the older malting quality standard Robust. Quest has higher $\beta$-glucan compared with Lacey.

\section{Disease Resistance}

Quest is resistant to stem rust race MCCF, which is used to detect the resistance gene Rpg1, and has the same marker haplotype for the gene specific marker for Rpg1 as Morex (CIho 15773; Rasmusson and Wilcoxson, 1979). Quest is not resistant to race TTKSK of $P$. graminis $\mathrm{f}$. sp. tritici, which is also known as Ug99. It is resistant to spot blotch, but is susceptible to Septoria speckled leaf blotch (Table 4).

Based on over 30 trials in the NABSEN, Quest has 47\% less disease and 38\% less DON compared to Robust (Table 5). Quest is not as resistant as Chevron, which is the Midwest six-rowed resistant check for FHB.
Table 5. Percentage Fusarium head blight (FHB) severity and deoxynivalenol (DON) levels for harvested grain samples from the North American Barley Scab Evaluation Nursery from 2004 to 2007, 2010, and 2011.

\begin{tabular}{lcccc}
\hline Cultivar & FHB & Sqrt(FHB) & DON & Sqrt(DON) \\
\hline \multirow{4}{*}{ Stander } & $\%$ & & $\mathrm{mg} \mathrm{kg}^{-1}$ & \\
Robust & 17.4 & 3.9 & 17.2 & 4.4 \\
Chevron & 13.3 & 3.4 & 11.9 & 3.6 \\
Conlon & 3.4 & 1.7 & 6.0 & 2.2 \\
Quest & 10.7 & 3.1 & 6.6 & 2.6 \\
No. of trials & 7.0 & 2.3 & 7.4 & 2.8 \\
HSD (0.05) & 33 & 33 & 26 & 26 \\
CV\% & 3.8 & 0.5 & 3.3 & 0.5 \\
\hline
\end{tabular}

TTukey's honestly significant difference $(\alpha=0.05)$.

\section{Availability}

Breeder seed is maintained by the Minnesota Agricultural Experiment Station, St. Paul, MN 55108. U.S. Plant Variety Protection of Quest is pending (PVP application no. 201100386). Small amounts of seed (5 g) are available for research purposes and can be requested from the corresponding author for at least $5 \mathrm{yr}$ from the date of this publication. It is requested that appropriate recognition of source be given when this cultivar contributes to development of new germplasm or cultivars.

\section{Acknowledgments}

The University of Minnesota barley breeding program is supported in part by the American Malting Barley Association, the Minnesota Agricultural Experiment Station, the USDA HATCH project MIN13-030, and the USDA-ARS Agreement No. 59-0790-4-120. This is a cooperative project with the U.S. Wheat and Barley Scab Initiative. Any opinions, findings, conclusions, or recommendations expressed in this publication are those of the author(s) and do not necessarily reflect the view of the U.S. Department of Agriculture. 


\section{References}

Canci, P.C., L.M. Nduulu, R. Dill-Macky, G.J. Muehlbauer, D.C. Rasmusson, and K.P. Smith. 2003. Genetic relationship between kernel discoloration and grain protein concentration in barley. Crop Sci. 43:1671-1679. doi:10.2135/cropsci2003.1671

Fetch, T.G., Jr., B.J. Steffenson, H.E. Bockelman, and D.M. Wesenberg. 2008. Spring barley accessions with dual spot blotch and net blotch resistance. Can. J. Plant Pathol. 30:534-542. doi:10.1080/07060660809507553

Fuentes, R.G., H.R. Michelson, R.H. Busch, R. Dill-Macky, C.K. Evans, W.G. Thompson, J.V. Wiersma, W. Xie, Y. Dong, and J.A. Anderson. 2005. Resource allocation and cultivar stability in breeding for Fusarium head blight resistance in spring wheat. Crop Sci. 45:1965-1972. doi:10.2135/cropsci2004.0589

Horsley, R.D., J.D. Franckowiak, P.B. Schwarz, and B.J. Steffenson. 1997. Registration of 'Foster' barley. Crop Sci. 37:1018. doi:10.2135/ cropsci1997.0011183X003700030075x

Horsley, R.D., J.D. Franckowiak, P.B. Schwarz, and B.J. Steffenson. 2006. Registration of 'Stellar-ND' barley. Crop Sci. 46:980-981. doi:10.2135/cropsci2005.06-0121

McMullen, M., S. Halley, B. Schatz, S. Meyer, J. Jordahl, and J. Ransom. 2008. Integrated strategies for Fusarium head blight management in the United States. Cereal Res. Commun. 36:563-568. doi:10.1556/ CRC.36.2008.Suppl.B.45

Mesfin, A., K.P. Smith, R. Dill-Macky, C.K. Evans, R. Waugh, C.D. Gustus, and G.J. Muehlbauer. 2003. Quantitative trait loci for Fusarium head blight resistance in barley detected in a two-rowed by six-rowed population. Crop Sci. 43:307-318. doi:10.2135/ cropsci2003.0307

Mirocha, C.J., E. Kolaczkowsk, W. Xie, H. Yu, and H. Jelen. 1998. Analysis of deoxynivalenol and its derivatives (batch and single kernel) using gas chromatography/mass spectrometry. J. Agric. Food Chem. 46:1414-1418. doi:10.1021/jf970857o

Nganje, W.E., D.A. Bangsund, F.L. Leistritz, W.W. Wilson, and N.M. Tiapo. 2004. Regional economic impacts of Fusarium head blight in wheat and barley. Rev. Agric. Econ. 26:332-347. doi:10.1111/ j.1467-9353.2004.00183.x

Rasmusson, D.C., and E.E. Banttari. 1975. Registration of Manker barley. Crop Sci. 15:603. doi:10.2135/cropsci1975.0011183X00150 0040049x
Rasmusson, D.C., K.P. Smith, R. Dill-Macky, E.L. Schiefelbein, and J.V. Wiersma. 2001. Registration of 'Lacey' barley. Crop Sci. 41:1991. doi:10.2135/cropsci2001.1991

Rasmusson, D.C., and R.D. Wilcoxson. 1979. Registration of 'Morex' barley. Crop Sci. 19:293. doi:10.2135/cropsci1979.0011183X00190 $0020032 x$

Rasmusson, D.C., and R.D. Wilcoxson. 1983. Registration of 'Robust' barley. Crop Sci. 23:1216. doi:10.2135/cropsci1983.0011183X0023 00060048x

Rasmusson, D.C., R.D. Wilcoxson, R. Dill-Macky, E.L. Schiefelbein, and J.V. Wiersma. 1999. Registration of 'MNBrite' Barley. Crop Sci. 39:290. doi:10.2135/cropsci1999.0011183X003900010059x

Rasmusson, D.C., R.D. Wilcoxson, and J.V. Wiersma. 1991. Registration of 'Excel' barley. Crop Sci. 31:227. doi:10.2135/cropsci1991.0011183 X003100010050x

Rasmusson, D.C., R.D. Wilcoxson, and J.V. Wiersma. 1993. Registration of 'Stander' barley. Crop Sci. 33:1403. doi:10.2135/cropsci1993.001 1183X003300060057x

Smith, K.P., D.C. Rasmusson, E. Schiefelbein, J.J. Wiersma, J.V. Wiersma, A. Budde, R. Dill-Macky, and B. Steffenson. 2010. Registration of 'Rasmusson' Barley 2010. J. Plant Reg. 4:167-170. doi:10.3198/jpr2009.10.0622crc

St. Pierre, S., C. Gustus, B.J. Steffenson, R. Dill-Macky, and K.P. Smith. 2010. Mapping net form net blotch and septoria speckled leaf blotch resistance loci in barley. Phytopathology 100:80-84. doi:10.1094/PHYTO-100-1-0080

Steffenson, B.J., J.D. Miller, and Y. Jin. 1993. Detection of the stem rust gene Rpg1 in barley seedlings. Plant Dis. 77:626-629. doi:10.1094/ PD-77-0626

Steffenson, B.J. 2003. Fusarium head blight of barley: Impact, epidemics, management, and strategies for identifying and utilizing genetic resistance. In: K.L. Leonard and W.R. Bushnell, editors, Fusarium head blight of wheat and barley. Am.Phytopath. Soc., St. Paul, MN. p. 241-295.

Toubia-Rahme, H., and B.J. Steffenson. 2004. Sources of resistance to septoria speckled leaf blotch caused by Septoria passerinii in barley. Can. J. Plant Pathol. 26:358-364. doi:10.1080/07060660409507153

Urrea, C.A., R.D. Horsley, B.J. Steffenson, and P.B. Schwarz. 2005. Agronomic characteristics, malt quality, and disease resistance of barley germplasm lines with partial Fusarium head blight resistance. Crop Sci. 45:1235-1240. doi:10.2135/cropsci2003.0608 